University of Nebraska - Lincoln

DigitalCommons@University of Nebraska - Lincoln

Publications of the University of Nebraska

Public Policy Center

Public Policy Center, University of Nebraska

2014

Sometimes We Do Reinvent the Wheel: Commentary on

MacDonald (1912)

Mario Scalora

University of Nebraska-Lincoln, mscalora1@unl.edu

Follow this and additional works at: https://digitalcommons.unl.edu/publicpolicypublications

Part of the Other Public Affairs, Public Policy and Public Administration Commons, Other Social and Behavioral Sciences Commons, Public Affairs Commons, Public Policy Commons, and the Social Policy Commons

Scalora, Mario, "Sometimes We Do Reinvent the Wheel: Commentary on MacDonald (1912)" (2014). Publications of the University of Nebraska Public Policy Center. 189.

https://digitalcommons.unl.edu/publicpolicypublications/189

This Article is brought to you for free and open access by the Public Policy Center, University of Nebraska at DigitalCommons@University of Nebraska - Lincoln. It has been accepted for inclusion in Publications of the University of Nebraska Public Policy Center by an authorized administrator of DigitalCommons@University of Nebraska - Lincoln. 


\title{
Sometimes We Do Reinvent the Wheel: Commentary on MacDonald (1912)
}

\author{
Mario J. Scalora \\ University of Nebraska-Lincoln \\ Correspondence: Mario J. Scalora, Department of Psychology, University of Nebraska-Lincoln, \\ 238 Burnett Hall, Lincoln, NE 68588-0308. E-mail: mscalora1@unl.edu
}

As a researcher of targeted violence, I found Arthur MacDonald's work "Assassins of Rulers" (MacDonald, 1912) very provocative. Although different norms for behavioral and criminological research early the past century may have limited the current applicability of Mac- Donald's findings, this work highlighted certain paradigmatic issues that have later emerged within the targeted violence literature. Before addressing commonalities with recent research, discussion of methodological issues is warranted. First, one is impressed with how detailed MacDonald's presentation is across the range of cases of political assassination and regicide. One wonders how more descriptive MacDonald's work would have been if he had access to the Internet and its vast array of sources in a 24-hr news cycle within our current information saturated culture. On

Published in Journal of Threat Assessment and Management 1:4 (2014), pp 241-242.

doi:10.1037/tam0000028

Copyright (C) 2015 American Psychological Association. Used by permission.

Submitted January 11, 2015; accepted January 12, 2015.

"This article may not exactly replicate the final version published in the APA journal. It is not the copy of record." 
the research methodology side, the applicability of MacDonald's findings may have been limited by both methodological limitations within his work as well as the limited utilization of behavioral threat assessment concepts by law enforcement during the early 20th century. Further, current researchers and journal reviewers would question MacDonald's limited sourcing, especially given the descriptive and declarative nature of his research. This study does not contain a research methodology section including sampling strategies, but instead engages in rather descriptive exposition of some of the relevant conditions and behaviors of assassins sampled. Noteworthy, however, is that MacDonald even includes near miss cases, though he does not make note of this distinction.

More striking about MacDonald's work are several commonalities with current research highlighted within his analysis. Consistent with the threat assessment literature in general, MacDonald asserts that such political violence was not impulsive but deliberative by asserting: "The assassins of rulers do not usually proceed in a sudden and blind way, like the insane, but their assaults are generally logically conceived and premeditated" (p. 505).

Such an assertion put MacDonald at odds with many previous violence frameworks that were impulsivity or pathology driven. It was not until Calhoun's (1998) work investigating violence toward the judiciary and the Exception Case Study (Fein \& Vossekuil, 1999) that researchers spent more time detailing the behavioral precursors and deliberative nature of targeted violence.

Consistent with the recent literature, MacDonald also noted that no set profile of assassins emerged, consistent with American and European research assessing violence toward political leaders (e.g., Fein \& Vossekuil, 1999; Meloy et al., 2004; James et al., 2008). In addition, those who engaged in such extreme violence also displayed a range of mental conditions and backgrounds (James et al., 2007, 2011; Meloy et al., 2004; Scalora et al., 2002a). MacDonald also detailed a range of attacker motives, though all of the motives cited justified the attack behavior (James et al., 2009; Scalora et al., 2002a). Further, many of the motives detailed were of personal value to the perpetrator (Scalora et al., 2002a, Scalora et al., 2002b; Calhoun \& Weston, 2009). MacDonald's detailed description of various attacker motivations also relates to political violence and terrorism research as he noted political extremism as motivating some of the attacks (e.g., Borum, Fein, \& Vossekuil, 2012). 
Within the current peer review environment, there is often pressure on researchers to detail the most recent and current literature to assure reviewers and editors that they are on top of the related research. Reviewing MacDonald's study highlighted for this author the need for researchers to be more humble in recognizing that we may be sometimes "reinventing the wheel."

\section{References}

Borum, R., Fein, R., \& Vossekuil, B. (2012). A dimensional approach to analyzing lone offender terrorism. Aggression and Violent Behavior, 17, 389-396. http://dx.doi. org/10.1016/j.avb.2012.04.003

Calhoun, F. S. (1998). Hunters and howlers: Threats and violence against federal judicial officials in the United States, 1789-1993. Arlington, VA: U. S. Department of Justice, U.S. Marshals Service.

Calhoun, F. S., \& Weston, S. W. (2009). Threat assessment and management strategies: Identifying the howlers and hunters. Boca Raton, FL: CRC Press.

Fein, R. A., \& Vossekuil, B. (1999). Assassination in the United States: An operational study of recent assassins, attackers, and near-lethal approachers. Journal of Forensic Sciences, 44, 321-333.

James, D. V., Mullen, P. E., Meloy, J. R., Pathé, M. T., Farnham, F. R., Preston, L., \& Darnley, B. (2007). The role of mental disorder in attacks on European politicians 1990-2004. Acta Psychiatrica Scandinavica, 116, 334-344. http://dx.doi. org/10.1111/j.1600-0447.2007.01077.x

James, D. V., Mullen, P. E., Meloy, J. R., Pathé, M. T., Preston, L., Darnley, B., .. Scalora, M. J. (2011). Stalkers and harassers of British royalty: An exploration of proxy behaviours for violence. Behavioral Sciences \& the Law, 29, 64-80. http://dx.doi. org/10.1002/bsl.922

James, D. V., Mullen, P. E., Pathé, M. T., Meloy, J. R., Farnham, F. R., Preston, L., \& Darnley, B. (2008). Attacks on the British Royal family: The role of psychotic illness. Journal of the American Academy of Psychiatry and the Law, 36, 59-67.

James, D. V., Mullen, P. E., Pathé, M. T., Meloy, J. R., Preston, L. F., Darnley, B., \& Farnham, F. R. (2009). Stalkers and harassers of royalty: The role of mental illness and motivation. Psychological Medicine, 39, 1479-1490. http://dx.doi. org/10.1017/S0033291709005443

MacDonald, A. (1912). Assassins of rulers. Journal of Criminal Law and Criminology, 2, 505-520. http://dx.doi.org/10.2307/1133046

Meloy, J. R., James, D. V., Farnham, F. R., Mullen, P. E., Pathe, M., Darnley, B., \& Preston, L. (2004). A research review of public figure threats, approaches, attacks, and assassinations in the United States. Journal of Forensic Sciences, 49, 1086-1093.

Scalora, M. J., Baumgartner, J. V., Zimmerman, W., Callaway, D., Hatch Maillette, M. A., Covell, C. N., ... Washington, D. O. (2002a). An epidemiological assessment of 
problematic contacts to members of Congress. Journal of Forensic Sciences, 47, 1360-1364.

Scalora, M. J., Baumgartner, J. V., Zimmerman, W., Callaway, D., Hatch Maillette, M. A., Covell, C. N., ... Washington, D. O. (2002b). Risk factors for approach behavior toward the U.S. Congress. Journal of Threat Assessment 2, 35-55. 